IIUC STUDIES

ISSN 1813-7733

Vol.- 6, June 2010 (p 97-110)

\title{
Note of Existentialism in the Poetry of Philip Larkin
}

\author{
Mohammad Taj Uddin*
}

\begin{abstract}
Existentialism became popular in the twentieth century, and it captured virtually every form of human thought and expression, including the novel, the theatre, poetry, art and theology. Though this philosophy had no specific system or sets of systems, yet it got a wide range of responses due to contemporary social circumstances. Individuals of the 20th century had a problematic existence with anguish, uncertainty, fear, alienation and despair because of different negative socio-political and cultural events that affected every aspect of life in Europe. Philip Larkin belonged to the same century and most of his poems present the typical problems of existence of an individual in the contemporary society. With an aim of better understanding of the poetry of Philip Larkin this paper explores how the poet, while dealing with the themes of his poetry, reflects the mood and ideas of existentialist philosophers. Since philosophy is closely connected with literature, as with other branches of knowledge, this study may help the readers understand Larkin's poetry from a new perspective.
\end{abstract}

Existentialism developed rapidly in $20^{\text {th }}$ - century Europe, and it influenced almost all aspects of thought in Europe. No great writer or poet could remain free from the influence of his time. Larkin was not an exception. He was influenced by the powerful mood of existentialism of his time. Larkin belonged to the $20^{\text {th }}$ century, and his poetry essentially reflects existential mood of his time. The whole atmosphere of Larkin's poetry is 'gloomy', 'bleak' and despairing. Larkin's fear for death and "extinction" intensifies the "gloom" and "terror" (Day, 1947 p.-74) in his poetry. So, temperamentally and linguistically the overall atmosphere of Larkin's poetry clearly reveals a strong note of existentialism.

\footnotetext{
* Lecturer, Department of English Language \& Literature, IIUC
} 
Existentialism is notoriously difficult to define. Existentialism is a philosophical idea, which gives priority to human existence, that is to say, subjective experience of the world, rather than to abstract or 'objective' structures or essences. According to "Oxford Advanced Learner's Dictionary" (Hornby, 2006-2007, p.532) existentialism is a philosophical theory, which says that humans are free and responsible for their actions in a "world without meaning." Oxford Advanced Learner's Dictionary" (Hornby, 1989, p.436) also says, it is a theory in philosophy derived from Kierkegaard, the Danish philosopher, and made popular by Sartre, the French philosopher, that man is a unique and isolated individual in a "meaningless and hostile world," responsible for his actions and free to choose his destiny. It is as much a mood or temper as it is a philosophical system. The claim of existentialists is that the existence of an individual is significant but has always been neglected by different systems such as philosophy, science, religion etc. (Stumph,1975,p.458-485). Though existentialism is largely identified with the French existentialist Jean Paul Sartre (1905-1980) and emerged in its contemporary form in Paris after World War II, the roots of existentialism and themes are varied. The roots are found in the work of Danish thinker Soren Kierkegaard, the Russian novelist Dostoyevsky and the German Philosopher Friedrich Nietzsche. The German phenomenologist Edmund Husserl, the French mathematician Pascal and philosopher Martin Heidegger, who influenced Sartre's philosophy, must be considered to be existentialist philosophers. There are some strange themes by which the existentialist philosophers express themselves in their writings about their concrete human existence in this absurd world of life and death. In spite of variations among the existentialists, they share some common feelings in dealing with such common themes as anxiety, death, alienation, nausea, despair, meaninglessness and nothingness of human existence. Existentialism also agrees with certain streams of thought in Judaism and Christianity that see human existence as "fallen" and human life as lived in suffering and sin, guilt and anxiety. ( Lavine, 1984,p.332) This dark and foreboding picture of human life leads existentialists to reject ideas such as happiness and optimism. The picture of life created by existentialists is highly pessimistic and depressive in every way.

However, the twentieth century was very important in terms of different social, political, and historical events. It was a time of frustration and loss of faith for the Western world. With the eruption of the First World War (1914), with the Communist Revolution in Russia in 1917 and later the Great Economic Depression of 1920s and 30s 
across Europe, many external authoritative structures crumbled down. All these events damaged not only the very confidence of people but also the optimism of future world of progress and peace (Abrahams, 1993, p.1825). Now individuals could retreat only into their individual self, rejecting all external authorities. Later, the Second World War (1939-45) was another blow to the confidence of people and people began to see instability, chaos and spiritual crisis everywhere.

One of Larkin's contemporaries is Ted Hughes. He argues that the advancements of the $20^{\text {th }}$-century philosophy, literature and science show that each man is hopelessly "isolated" and "alienated". "Each man, he says, is isolated in his existential agony in a universe the 'teleology' (purpose) of which man can't understand.' Regarding the uncertain purpose of the world and human existence Kierkegaard, one of the forerunners of existentialism, says:

"I stick my finger into existence...it smells of nothing. Where am I? What is this thing called the world? Who is it who has lured me into the thing, and now leaves me here? Who am I?" (Lavine, 1984, p.322).

Kierkegaard also says that the life of every modern man is lived in anxiety because of the meaninglessness and nothingness of human existence. He also suggests a religious solution to the problem by saying that a "leap of faith to God" (Lavine, 1984, p.323) can solve the meaninglessness and anxiety of a modern man.

In the poem 'Song for a Phallus', Ted Hughes wants to say that modern life is in a state of chaos. Also, T.S. Eliot reminds us of spiritual barrenness and 'despair' (Kaplan, 17-50) in the western world in his poems, 'The Waste land' and 'The Love Song of J. Alfred Prufrock'. Whatever they say is related to the existence and spiritual problems of an individual in the contemporary society. Perhaps, the root cause of all problems is loss of faith, along with the death of old values in twentieth century Europe.

Philip Larkin being one of those who belonged to the $20^{\text {th }}$ century was not free from the influence of existentialism. Notably, Philip Larkin was a poet laureate of twentieth century England. He was born in Coventry in 1922. His father was a City Treasurer, and in 1930 Larkin entered King Henry VIII School. In 1940 he went to St. John's College to study 
English there. This was early in the Second World War, and he was able to complete his degree (Honors) in 1943. (Motion, 1993, p.36-150).

Throughout Larkin's poetry there is a continuing interest in the "nature of human existence" (However agnostic) (Linda \& Bryn, 1989, p. 91). So the poetry of Philip Larkin creates a strong note of existentialism in different ways, especially when he deals with his central theme, that is, death. All other themes of Larkin revolve round this theme and all themes reveal a strong note of pessimism.

In the poem, "Church Going" Larkin presents the typical agnosticism of the $20^{\text {th }}$ century as well as his own existential dilemma. He seems to be mocking at church rituals at different levels, but at the same time he feels the necessity of this house (church) on this earth for the consolation of mind of its visitors:

A serious house on serious earth it is, In whose blent air all our compulsions meet Are recognized and robbed as destinies.

Line: 55-57, "Church Going”

Larkin's attitude to church is sarcastic, and ironically he rejects the religious purpose of church. He indicates that visiting church is wasting of time. In spite of it he often visits church:

Yet stop I did: in fact I often do, And always end much at a loss like this, Wondering what to look for...?

Line: 19-21, "Church Going"

The sense of isolation and alienation is created with the words such as, 'much at a loss' and 'what to look for'. It is an existential problem that one cannot easily identify one's feelings with external phenomena. Larkin's sense of isolation is further deepened when he says that he visits the church alone, when nobody is there. He observes all things inside the church and feels the 'otherness' of these things, but is unable to find meanings.

We can remember how Sartre, the French existentialist, thinks about his 'car', its 'seat' and 'seat-belt' or his cigarette packet and tries to understand them and their relationship with him. (Lavine, 1984, p.344). Larkin is in a kind of fantasy when he observes different things 
inside the church, and thinks about these things in terms of the future. As Larkin says:

Once I am sure there is nothing going on I step inside, letting the door thud shut. Another church: matting, seats. And stone, And little books, sprawling of flowers, cut For Sunday, brownish now; some brass and stuff Up at the holly end; the small neat organ; And a tense musty, unignorable silence, "Church Going", Line: 1-7

Larkin describes the things inside the church seemingly in a respectful manner, but his tone has an implied sense of mockery; and so all things that he describes are isolated from his real sense of agnosticism. In tone and language a sense of distance is maintained between the poet's real feeling of agnosticism and the holy purpose of church.

Again, a sense of frustration, which is characteristic of existentialism, is created from Larkin's outlook on loss of beauty, change of time, old age, brevity of fame and lack of communication among the persons living together and so on. All individuals are shocked at the thought of the gap between their hopeful past and the hopeless present. 'Lines on a Young Lady's Photograph Album' presents the poet's feeling of disgust or nausea. An ambivalent attitude to the pictures of the album is seen. The pictures of the album and some backgrounds of few pictures cause strong distress to the poet because the lady's past has come to an end. The poet mourns the loss of beauty of the lady who is seen in the pictures. When we human beings are no longer what we used to be in the past we feel a great pain and we are also pained by feeling of our freedom to cry for a loss:

At last you yielded up the album, which, Once open, sent me distracted. All your ages

Matt and glossy on the thick black pages!

Too much confectionary, too rich: I choke on such notorious images. Lines: 1-5, "Lines on a Young Lady's Photograph Album."

In another stanza he also writes:

Yes, true; but in the end, surely, we cry 
Not only at exclusion, but because

It leaves us free to cry. We know what was

Won't call on us to justify

Our grief, however hard we yowl across

The gap from eye to page. So I am left

To mourn (without a change of consequence),

Stanza, 7 ,

"Lines on a Y. Lady's P. Album".

In this regard we can remember Sartre's saying, 'individuals are condemned to be free'. (Lavine, 1984,p.349). 'Love Song in Age' is somewhat cynical appraisal of the nostalgic mood, the linking of the present with the past and the failure to achieve fulfillment in life. 'Talking in Bed' constantly reveals sense of isolation and alienation. Limitations of physical intimacy and problems of non-communication are the features that create sense of frustration in 'Talking in Bed'. The following lines read as follows:

Talking in bed ought to be easiest;
Lying together there goes back so far,
An emblem of two people being honest.
Yet more and more time passes silently.
Outside, the wind's incomplete unrest
Builds and disperses clouds in the sky,
And dark towns heap up on the horizon.
None of this cares for us. Nothing shows why
At this unique distance from isolation
It becomes still more difficult to find
Words at once true and kind,
Or not untrue and not unkind.
Lines: $1-12$, 'Talking in Bed'

'Home is so Sad' creates a sense of alienation between the narrator of the poem and the past inhabitants of the house. The alienation lies in between the change of time that is, the present and the past. This poem indicates that life at home is as sad and meaningless as life outside. 'At Grass' deals with the themes of change, age and differences. The poem talks about some old racehorses, which were very famous, got recognition in the past for their performance, but now are waiting for death. So fame is very temporary. It also indicates that all individuals are free to do or act for themselves for fame or gain. And our existence is both freedom and despair. It is despair because some constraints of time, place and conventions still control our movements and life. This is frustrating. 
However, Larkin is famous as a poet of death. He fears death because it ends his existence. Though Larkin has his own way of presenting death-theme in his poetry, his mood with death shows a strong influence of existentialism. In existentialism death appears as a "boundary situation", defining the limits of existence. When Larkin talks about death he brings up the issues of religion and rejects religious ideas of death. Religion is completely "unable to console him" (Day, 1987, p.74). As far as religion is concerned, Larkin's approach to death is seemingly an atheistic approach. As to religion, there are two lines in existentialism. One approach is religious and another is atheistic. It may also be said about Larkin that his mood is a mood of an existentialist in dealing with death, but virtually he follows neither religious nor atheistic approach; because he seems to be rejecting both Kierkegaard, the Danish religious existentialist and Fredrick Nietzsche, the German existentialist in his poem, 'Aubade'. About his fear of death he says:

This a special way of being afraid No tricks dispel. Religion used to try, That vast moth-eaten musical brocade Created to pretend we never die, 'Aubade', Line: 21-24

Kierkegaard's opinion is that the ultimate faith in God can dispel the meaninglessness and nothingness of human existence. As religion says, there is another life after death or death is just a transfer to another world. Larkin, whose existence and obsession are connected with death, could have dispelled the fear of death from his mind, if he would have believed in such religious theory. But he does not believe in religion. Rather he does say that religion ('vast moth-eaten musical brocade') was created for convincing the gullible to say that death was avoidable.

In contrast to Larkin, if we read American poet Walt Whitman, he writes:

Do you see oh my brothers and sisters?

It is not chaos or death-it is form, union, plan-it is happiness.

“Song of Myself”, Section: 50, Lines: 1316-1318.

And as to you death, you bitter hug of mortality, It is idle to try to alarm me.

'Song of Myself', Section: 49, Line: 1 
To Whitman death is a part of great plan of Almighty God. Through a sense of spirituality, Whitman expresses that death is as important as life. Death and life have meanings and purpose. So death is not a matter of fear for him. Whitman's realization of death as a part of God's plan in the whole universe gives him consolation and peace. He triumphs over the harsh realities of his life and existence with his faith. Similarly, Dylan Thomas considers life, death and birth to be a process as a whole. Whitman faces death like the religious existentialists, who face death and despair with their faith in God. But Larkin has no such faith.

In the same poem, 'Aubade' Larkin seems to be referring to, and rejecting the solution given by Nietzsche. Nietzsche says that modern man can remove his existential crises by getting back his "courage" (Lavine, 1984) and by rejecting old Judaism and Christianity a modern man can be intellectually free and happy. According to Nietzsche bravery is to be restored. But Larkin, who closely associated death with his existence, can't accept Nietzsche's words. Larkin writes:

Courage is no good:

It means not scaring others. Being brave

Lets no one off the grave.

'Aubade', Line: 37-39

Larkin's realization is that no one can escape death or grave no matter how much one is brave. Larkin maintains his dread of death throughout his poems. His dread is similar to the dread of the existentialists who are also confused with their existence. Larkin has rightly been accused of pessimism, deep sadness and despair and he was very "explicit in his rejection of the belief of orthodox or traditional religion" (Linda \&Bryn, 1989, p.92).

By rejecting religious ideas about death or any established set of beliefs on death, Larkin only senses 'emptiness' or 'vacuum' after death; and he is in a state of total chaos. Even he is so much obsessed with death that he cannot but think of it all the time. Death is a serious issue for Larkin. He does not embrace Sartre's mild sayings: "Death is as absurd as birth" or "what is death?' "Death means my total non-existence", but he embraces rather the terrifying saying of another great existentialist, Martin Heidegger, who says, "My death is my most authentic, significant moment, which I alone must suffer," (Lavine, 1984, p.332).

It is true that Larkin has to face his death like other men, and this death will bring an end to his existence. But the problem is aggravated more because Larkin is not sure like us why we die. 'We have lack of 
knowledge about the aftermath of death' he says. He expresses his inability of knowing the real results after death in a poem, "Ignorance". Though ignorance of a petty matter does not, but the ignorance of a serious issue, directly related to our existence, intensifies our sorrow. The inquiry about the aftermath of death and ignorance about it are universal conditions of all individuals. Larkin's fear and frustration mainly spring from his incapacity to know what exactly happens after death except 'extinction' and 'void'. As already mentioned, Larkin could have avoided the fear of death, if he would have accepted the religious idea telling the story of the after- world. (Linda \& Bryn, 1989, p. 84-85).

Why Larkin is so afraid of the 'void' or 'emptiness' after death, however, becomes clearer, when we read the few lines from another great French mathematician and existentialist named Pascal. He talks about his own existence in the world and short duration of his life:

"When I consider the short duration of my life swallowed up in the eternity before and after, the little space I fill, and even can see, engulfed in the infinite immensity of space of which I am ignorant, and which knows me not, I am frightened, and am astonished at being here rather than there, why now rather than then.' (Lavine, 1984, 331).

Larkin echoes Pascal in tone and expresses the same fear of void and emptiness in the following lines:

The mind blanks at the glare. Not in remorse ....... The good not done, the love not given, time Torn off unused---nor wretchedly because An only life can take so long to climb Clear of it long beginnings, and may never:

But at the total emptiness for ever, The sure extinction that we travel to And shall be lost always. Not to be here Not to be anywhere, And soon nothing more terrible, nothing more true. (Lines: 11-29, Aubade)

Just as the meaninglessness and nothingness of human existence cause the anxiety and despair of Kierkegaard and Nietzsche, the meaninglessness of the non-existence due to death causes the same despair and fear in Larkin's mind. Then, after death the 'vast dark 
unknown region', which is mere emptiness for Larkin, caused the fear in his mind for death. The thought of complete 'extinction' of his existence is the cause of fear and anxiety. From such universal questions regarding one's own existence and then non-existence because of death, a truth becomes clear that man's lack of knowledge about the purpose of his 'being here' (the world) or 'being there' (region after death) aggravates man's painful situation. It is such a knowledge that can't be derived through reason or practical wisdom other than what religion says. But already Larkin, as an agnostic or an atheist has rejected the "moth-eaten brocade" i.e. religion. Larkin's condition is typical of the growing agnosticism during his time. So having nothing (religion or ideas et.) to depend on or to believe in, Philip Larkin is afraid of death and emptiness after death. (Day, 1987, p.74).

To contemplate death in terms of vacuum is disturbing: it makes life itself an object of multifarious and painful wonder. This feeling is also expressed in 'The old Fools' (High Windows), where the vacuum that preceded our birth is compared with the vacuum ahead of us:

At death, you break up: the bits that were you Start speeding away from each other for ever With no one to see. It's only oblivion, true: We had it before, but then it was going to end, And all the time merging with a unique endeavor To bring to bloom the million-petalled flower Of being here. Next time you can't pretend There will be anything else.

'The old Fools', L.13-20

Besides mentioning the "oblivion" of the old men, "The old Fools" refers to the alienated world of the old men. (Day, 1987, p.73).

Shakespeare, John Donne, Emily Dickinson and other poets also deal with the questions of life, death, and existence. Larkin is the most pessimistic of all. Shakespeare, for example, expresses a problematic attitude to death in one of Hamlet's famous speeches, "to be or not to be that is the question-." Hamlet's indecision in Hamlet regarding suicide raises some questions, 'where will he go after death?', 'what is death like?' 'Is death like just sleep?' or, 'Is death like just dreams where we see disturbing night mares?' "What happens after death?' All these questions are related to existence:

To die, to sleep- 
No more: and by a sleep to say we end,

To die, to sleep-

To sleep, perchance to dream. Ay, there's the rub, For in that sleep of death what dreams may come, When we shuffle off the mortal coil,

Hamlet Act-III,

Donne is not afraid of death because he, unlike Larkin, believes in God and mercy of God:

One short sleep past, wee wake eternally, And death shall be no more, Death thou shall die.

(Lines: 13-14, Holly sonnet-X).

Dickinson and Frost are pessimistic in dealing with death, but Philip Larkin is more pessimistic than all of them together. Perhaps, Larkin is the most pessimistic voice in the whole English literature. Shakespeare, who compares death to sleep like Donne, is more philosophical than Donne and Larkin. Shakespeare reveals a sense of uncertainty as to the real happenings after death like Larkin. In this regard Shakespeare is very close to Larkin's sense of uncertainty after death and Larkin himself at the same time is close to Hamlet's melancholic or depressing mood. Nietzsche's comment on one of Hamlet's speeches 'To be or not to be' is a profound one. He says, "understanding kills action" or "it is understanding which debars action of Hamlet not reflection: "the apprehension of truth and its terror". (Edwards, 35) Similarly, the understanding of Larkin is an understanding of the 'emptiness of existence and his 'final nonexistence' after death that creates terror in his mind. The same mind of inaction and boredom of life is found in some poems of Larkin, as if Larkin were another Hamlet in thought or another Macbeth in mental agony, though not physically in the real sense.

In "Dockery and Son" Larkin delineates the most frustrating picture of our life and existence. In "Dockery And Son" marriage, which is a kind of social commitment, has been neglected by him. This poem shows what happens to an individual when his feelings are alienated from the larger will of society. In "Dockery and Son" when he faces the question of the gain (marrying, family, and children) and loss (not marrying, not having family, and children) of life in terms of death, he comes to the conclusion:

Life is first boredom, then fear. 
Whether or not we use it, it goes, And leaves what something hidden from us chose, And age, and then the only end of life.

("Dockery and Son",Line.44-47)

Life is also a matter of different choices, but all choices are not always matched with our existence. And, also all choices are not easy to be made. Interestingly, the following philosophical lines of Shakespeare in Macbeth regarding meaninglessness of our life echo the sense of loss and meaninglessness of life and death expressed in Larkin's poem (Braunmuller, p. 2290). In Shakespeare's Macbeth, when Macbeth is bewildered with the situation and existence of his life he makes the following comments on life and our absurd existence:

Life's but a walking shadow, a poor player

That struts and frets his hour upon the stage

And then is heard no more. It is a tale

Told by an idiot, full of sound and fury

Signifying nothing.

Macbeth, Act: V, Lines: 23-27,

In his poem 'Ambulances', Larkin exposes his thought delineating life and its activities as meaningless, as we are all going to die like the one being carried in the ambulance. We can understand, Larkin wants to say, the emptiness of our life while watching an ambulance with a dying or sick man:

And sense the solving emptiness

That lies just under all we do, And for a second get it whole, So permanent and blank and true.

The fastened doors recede. Poor soul, They whisper at their own distress.

(“Ambulances", L.13-18)

Larkin wants to say that whatever we do in our life is meaningless because of death, and we live our complete life in mere emptiness in a meaningless world. "Ambulances" indicates that a sick man is alone; when he dies he is more alone.

The frustrating pictures of our life and existence shown by Larkin or by Shakespeare prove that we are not really able to change the course of our life and death. If individual's inability to change the course of 
life and death create frustrations, the understanding of it creates the same and farther aggravates the situation.

What Heidegger, the existentialist, thinks about his life is somewhat similar to Larkin's. Heidegger (1889-1976) says that when he thinks of death everything seems to be meaningless. Whatever we do will be nothing in the face of death. Heidegger says, "The whole of my being seems to drift away into nothing. The unaware person tries to live as if death is not actual, he tries to escape its reality.' (Lavine, 1984, p.332). Like Heidegger Larkin is obsessed with death and finds his existence filled with anxiety, despair and nothingness. The way he presents the isolation of a sick man from the rest of the world inside an ambulance is remarkable:

Far

From the exchange of love to lie

Unreachable inside a room

The traffic parts to let go by

Brings closer what is left to come,

And dulls to distance all we are. ,

(“Ambulances”, Lines: 25-36.)

Philip Larkin's poetry is affected by anguish, loneliness and anxiety. He is an individual sufferer concerned with death, old age, and brevity of life and meaninglessness of his existence. However, Philip Larkin's thought about death is also fragmentary; is based on his individual petty consciousness of the present and known existence rather than the larger consciousness of the vast eternity here and hereafter. As an agnostic he values the present, and he thinks about the situation after death basically by the present; and he does not care what religion says or what the sets of beliefs talk about the after world. So, though his thought on death is terrifying, it is narrow. And all his existential agonies come from his pessimistic outlook on death, life, old age, change of nature, meaningless busy life of men and women, and so on. The change and renewal of the nature, the dread of the future, death: such listing of the subject- matters of Larkin's poems quickly runs itself into "flat abstractions" (Thwaite, 1985, p. 40). Larkin is concerned to address ideas rather than any theory and, is always preoccupied with such English traditional themes - death, love, time - that these concepts are related to specific situations, which he experiences with his conscious existence. Various frustrating aspects of Larkin's experiences and existence thus constitute a strong note of existentialism in his poetry. 
Therefore, the study above shows that the poetry of Philip Larkin is profuse in the ideas and mood of existentialism.

1. All the extracts of Larkin's poetry are taken from :(a). ABRAHAMS, M.H. (1993); The Norton Anthology of English Literature, Vol. 2, Sixth Edition, New York and London, W.W.Norton Company Inc. and (b): www.Poemhunter.com respectively.

\section{References:}

ABRAHAMS, M.H. (1993); The Norton Anthology of English Literature, Vol. 2, Sixth Edition, New York and London, W.W.Norton Company Inc. pp.1825

DAY, ROGER, (1987); Larkin, Open University Press, Great Britain, P. 74.

DONNE, JOHN, (1983); Selected Poems, Edit. Philip Mallett, Long man, York Press, Essex, England

HORNBY, A.S. (1989); Oxford Advanced Learner's Dictionary of Current English, Oxford University Press, Fourth Edition, New York.

HORNBY, A.S. (2006-2007); Oxford Advanced Learner's Dictionary of Current English, Oxford University Press, Sixth Edition, New York, and New Delhi.

KAPLAN, ROBERT, (1991); T. S. Eliot's Major Poems \& Plays, Cliffs, New Delhi, India, P.17-19.

LAVINE, T.Z. (1984); From Socrates to Sartre, The Philosophic Quest, A Bantham Book, New York, London, Sydney, Auckland.

LINDA \& BRYN, (1989); Critical Essays On Philip Larkin: The Poems, Longman Literature Guide, UK, p.91.

MOTION, ANDREW, (1993); Philip Larkin, A Writer's Life, Faber and Faber Limited, England, p.36-190.

SHAKESPEARE, WILLIAM, (1975); Hamlet, prince of Denmark, edit, Philip Edwards, Cambridge University Press, New Delhi, India

SHAKESPEARE, WILLIAM, (1997); Macbeth, edit Braunmuller, Cambridge University Press, First South Asian Edition, , Asia Foundation, New Delhi.

STUMPF, SAMUEL ENOCH, (1975); Socrates to Sartre, A History of Philosophy, Second Edition, McGraw-Hill Book Company, New York, USA.

THWAITE, ANTHONY (1985); Poetry Today-A critical Guide to British Poetry, Longman, New York, USA

WHITMAN, WALT, (1973); Leaves of Grass and Other Writings, edit. Michel Moon, WW. Norton \& Company, New York. London.p.75-78 